\title{
The Pact of Bogota: Cases and Practice
}

Fecha de recepción: 22 de febrero de 2016

Fecha de aceptación: 6 de mayo de 2016

Doi: 10.12804/revistas.urosario.edu.co/acdi/a.5294

\section{María Teresa Infante Caffi}

Abstract: The jurisdiction of the International Court of Justice (ICJ) under the Pact of Bogota $(1948)^{1}$ is part of a system of norms attributing competence to the referenced tribunal along with other means of settlement. The system sets out principles and general exceptions applicable to all the means of peaceful settlement embodied in the Pact. This study will review specific cases that show how the instrument has operated, along with the main debates relative to its efficiency and reform. While the first topic relates to the theory of dispute settlement and treaty interpretation under general international law, the second is linked to the dynamics of the Inter-American System, its institutional components and the perspectives of reform. Finally, the Pact has not been exempt from the influence of hemispheric politics and diplomacy.

Key words: Judicial jurisdiction, International Court of Justice, Pact of Bogota, hemispheric system of dispute settlement.

* Professor of International Law University of Chile. Former Director of Frontiers and Limits, Ministry of Foreign Affairs; former Director of the Institute of International Studies at the University of Chile. Ambassador to the Netherlands. Co-Agent of Chile before the ICJ in the case of Peru v. Chile. E-mail: minfante@minrel.gov.cl

1 American Treaty on Pacific Settlement, 30 April 1948, OAS, Treaty Series Nos. 17 and 61. Available at: https://treaties.un.org/doc/Publication/unTs/Volume\%2030/v30.pdf. Thirteen States are parties to the Pact and 2 states, Colombia and El Salvador, have denounced it.

Para citar este artículo: Infante Caffi, M. T., "The Pact of Bogota: cases and practice", Anuario Colombiano de Derecho Internacional (ACDI), 2017, 10, pp. 85-116. Doi: 10.12804/revistas.urosario.edu.co/acdi/a.5294 
Resumen: la jurisdicción de la Corte Internacional de Justicia conforme al Pacto de Bogotá forma parte de un sistema de normas que atribuyen competencia a dicho tribunal, así como a otros medios de solución. El sistema establece principios y excepciones generales que se aplican a todos los medios de solución previstos en tal instrumento. Este trabajo pasa revista a casos específicos que muestran cómo ha operado el Pacto, así como también a los principales debates relativos a su eficacia y reforma. Mientras que el primer tema se relaciona con materias de derecho internacional general sobre la solución de controversias y la interpretación de los tratados, el segundo ámbito se vincula a las dinámicas del Sistema Interamericano, sus componentes institucionales y las perspectivas de una reforma. Finalmente, el Pacto no ha sido ajeno a la política y diplomacia hemisféricas.

Palabras clave: jurisdicción judicial, Corte Internacional de Justicia, Pacto de Bogotá, sistema hemisférico de solución de controversias.

\section{O Pacto de Bogotá: Casos e Prática}

Resumo: A jurisdição da Corte Internacional de Justiça conforme ao Pacto de Bogotá forma parte de um sistema de normas que atribuem competência a dito tribunal, assim como a outros meios de solução. O sistema estabelece princípios e exceções gerais que se aplicam a todos os meios de solução previstos em dito instrumento. Este trabalho passa revista a casos específicos que mostram como tem operado o Pacto, assim como também, aos principais debates relativos à sua eficácia e reforma. Enquanto que o primeiro tema se relaciona com matérias de direito internacional general sobre a solução de controvérsias e a interpretação dos tratados, o segundo âmbito se vincula às dinâmicas do Sistema Interamericano, os seus componentes institucionais e as perspectivas de uma reforma. Finalmente, o Pacto não tem sido alheio à política e diplomacia hemisféricas.

Palavras-chave: Jurisdição judicial, Corte Internacional de Justiça, Pacto de Bogotá, sistema hemisférico de solução de controvérsias. 


\section{The Pact of Bogota as a source for the compulsory jurisdiction of the ICJ}

The American Treaty on Pacific Settlement, or the "Pact of Bogota", adopted at the Ninth International Conference of American States in 1948, relates to the structure of the Inter-American System while remaining independent from the Charter of the Organization of American States (OAS), which sets forth the political premises of the System. ${ }^{2}$ The Pact inherits proposals already advanced by the Inter-American Juridical Committee since 1945, when a draft Inter-American System of Peace emerged. ${ }^{3}$ Draft studies conducted over the years $1938-45$ and the work of the Inter-American Juridical Committee to coordinate and systematize Inter-American Peace Agreements had shown preferences for a combination of procedures for dispute settlement, including voices in favor of a regional court. On the whole, the concept of an Inter-American System of Peace was enshrined at the Chapultepec Conference. ${ }^{4}$

Judicial and arbitral procedures subsequently took center stage in the discussion in Bogota, resulting in an innovative scheme of compulsory jurisdiction subject to limits and exceptions. ${ }^{5}$

2 A historical introduction to the System can be found in The Inter-American System. Treaties, Conventions \& Other Documents. Vol. I, Legal - Political Affairs, Part I, a compilation annotated by F. V. García Amador, Historical Introduction, London; New York: Oceana Publications, 1983, pp. 1-66.

3 Anteproyecto de 'Sistema Interamericano de Paz e Informe Anexo'. Comité Jurídico Interamericano, 1945, Unión Panamericana, Washington 6, D.C., Octubre 1945. Also see A. Lleras, "El Pacto de Bogotá y la OEA". Informe sobre la IX Conferencia Internacional Americana. Antología, Vol. V. El Diplomático, pp.128-247, in O. Morales Benítez, Bogotá, Villegas Editores, 2006. http://jorgeorlandomelo.com/bajar/pactodebogota.pdf (accessed 1 June 2015). Also, E. Valencia-Ospina, "The Role of the International Court of Justice in the Pact of Bogota", in Liber Amicorum 'In Memoriam' of Judge José María Ruda, The Hague: Kluwer, 2000, pp. 296-299.

4 Conferencia Interamericana sobre Problemas de la Guerra y de la Paz: Informe sobre los Resultados de la Conferencia presentado por el Consejo Directivo de la Unión Panamericana, México, D.F.; febrero 21 -marzo 8, 1945. Unión Panamericana, Washington D.C., 1946, serie sobre Congresos y Conferencias N 47, Resolución XXXIX. Also G. Connell Smith, The Inter-American System, London, Oxford University Press, 1966, pp. 209-210.

5 J. C. Lupinacci, "Los procedimientos jurisdiccionales en el Tratado Americano de Soluciones Pacíficas (Pacto de Bogotá)", Anuario Uruguayo de Derecho Internacional, 1962, pp. 174-183; E. Jiménez de Aréchaga, "Tentativas de reforma del Pacto de Bogotá", Anuario Jurídico Interamericano, 1986, pp. 3-11; M. T. Infante Caffi, "El Pacto de Bogotá. Vigencia y 
For decades, authors saw the Pact of Bogota as an outdated instrument whose impracticality lay in its provisions themselves and in the lack of a common purpose, leading to reservations addressed to its general principles. ${ }^{6}$ Subsequent references to the Pact in different cases before the Court have revealed other facets of the instrument. ${ }^{7}$ The scope and technicalities of the Pact have been made apparent by successive judicial processes where its clauses have called for interpretation, demonstrating the complexities of the interplay between general principles and the jurisdiction of the Court as one of the fundamental characteristics of the Pact. This has been evidenced by significant reservations made by Bolivia, ${ }^{8}$

propuesta de reforma', Comité Jurídico Interamericano, Cursos de Derecho Internacional, Vol. 2 (Parte 1), El Sistema Interamericano (1974-2001), pp. 1043-1063; E. Valencia-Ospina, "The Role of the International Court of Justice in the Pact of Bogota", in Liber Amicorum In Memoriam' of Judge José María Ruda, The Hague, Kluwer, 2000, pp. 296-299.

6 A. Gómez-Robledo Verduzco, "El 'Pacto de Bogotá' sobre solución de controversias a la luz del caso relativo a las acciones armadas fronterizas y transfronterizas entre Nicaragua y Honduras (CIJ)", in El Papel del Derecho Internacional en América, Universidad Nacional Autónoma de México, The American Society of International Law, México, 1997, pp. 179-204. Views of Ecuador (1973) aiming to revise the Pact of Bogota, in Organización de los Estados Americanos, Comisión Especial para Estudiar el Sistema Interamericano y Proponer Medidas para su Reestructuración. OEA/Ser.P CEESI/doc.26/73. Vol. IV Parte 2, 8 noviembre 1973, p. 195.

Border and Transborder Armed Action (Nicaragua v. Honduras), Jurisdiction and Admissibility, Judgment, ICJ, Reports 1988; Territorial and Maritime Dispute between Nicaragua and Honduras in the Caribbean Sea (Nicaragua v. Honduras), Judgment, ICJ Reports 2007; Territorial and Maritime Dispute (Nicaragua v. Colombia), Preliminary Objections, Judgment, ICJ Reports 2007; Dispute regarding Navigational and Related Rights (Costa Rica v. Nicaragua), Judgment, ICJ Reports 2009; Aerial Herbicide Spraying (Ecuador v. Colombia), ICJ Reports 2008 (discontinued); Maritime Dispute (Peru v. Chile), ICJ Reports 2014; Construction of a Road in Costa Rica along the San Juan River (Nicaragua v. Costa Rica) Judgment, ICJ, Reports 2015; Certain Activities Carried out by Nicaragua in the Border Area (Costa Rica v. Nicaragua) Judgment, ICJ, Reports 2015; Obligation to Negotiate Access to the Pacific Ocean (Bolivia v. Chile), (pending); Maritime Delimitation in the Caribbean Sea and the Pacific Ocean (Costa Rica v. Nicaragua) (pending); Alleged Violations of Sovereign Rights and Maritime Spaces in the Caribbean Sea (Nicaragua v. Colombia), pending; Question of the Delimitation of the Continental Shelf between Nicaragua and Colombia beyond 200 Nautical Miles from the Nicaraguan Coast (Nicaragua v. Colombia), pending.

8 "The Delegation of Bolivia makes a reservation with regard to Article VI, in as much as it considers that pacific procedures may also be applied to controversies arising from matters settled by arrangement between the Parties, when the said arrangement affects the vital interests of a state". The reservation made at the time of signature and ratified in 
Ecuador, ${ }^{9}$ and Peru, ${ }^{10}$ and those postulated by Argentina (signatory), ${ }^{11}$ as

2011 was withdrawn in 2013, on the eve of submitting a claim against Chile before the ICJ. Signatories and Ratifications, Pact of Bogota. Available at: http://www.oas.org/juridico/ english/sigs/a-42.html\#Bolivia

9 Ecuador: "The Delegation of Ecuador, upon signing this Pact, makes an express reservation with regard to Article VI and also every provision that contradicts or is not in harmony with the principles proclaimed by or the stipulations contained in the Charter of the United Nations, the Charter of the Organization of American States, or the Constitution of the Republic of Ecuador". Signatories and Ratifications, Pact of Bogota. Available at: http://www.oas.org/juridico/english/sigs/a-42.html\#Ecuador

10 Peru:

"1. Reservation with regard to the second part of Article V, because it considers that domestic jurisdiction should be defined by the state itself.

2. Reservation with regard to Article XXXIII and the pertinent part of Article XXXIV, inasmuch as it considers that the exceptions of res judicata, resolved by settlement between the parties or governed by agreements and treaties in force, determine, in virtue of their objective and peremptory nature, the exclusion of these cases from the application of every procedure.

3. Reservation with regard to Article XXXV, in the sense that, before arbitration is resorted to, there may be, at the request of one of the parties, a meeting of the Organ of Consultation, as established in the Charter of the Organization of American States.

4. Reservation with regard to Article XLV, because it believes that arbitration set up without the participation of one of the parties is in contradiction with its constitutional provisions.

Peru confirmed the reservations at the time of the ratification".

On February 27th, 2006, Peru notified the General Secretariat of the OAS of the withdrawal of the reservations made to articles V, XXXIII, XXXIV, XXXV and XLV of the American Treaty on Pacific Settlement, "Pact of Bogota". Signatories and Ratifications, Pact of Bogota. Available at: http://www.oas.org/juridico/english/sigs/a-42.html\#Perú 11 Argentina:

"The Delegation of the Argentine Republic, on signing the American Treaty on Pacific Settlement (Pact of Bogota), makes reservations in regard to the following articles, to which it does not adhere:

1) Article VII, concerning the protection of aliens:

2) Chapter Four (Articles XXXI to XXXVII), Judicial Procedure:

3) Chapter Five (Articles XXXVIII to XLIX), Procedure of Arbitration;

4) Chapter Six (Article L), Fulfillment of Decisions.

Arbitration and judicial procedure have, as institutions, the firm adherence of the Argentine Republic, but the Delegation cannot accept the form in which the procedures for their application have been regulated, since, in its opinion, they should have been established only for controversies arising in the future and not originating in or having any relation to causes, situations or facts existing before the signing of this instrument. The compulsory execution of arbitral or judicial decisions and the limitation which prevents the states from judging for themselves in regard to matters that pertain to their domestic 
well as the positions taken by Venezuela (signatory). ${ }^{12}$ Fenwick's comments on some of these reservations confirm the conclusion above, ${ }^{13}$ which has remained valid. Under Articles LV and LVI, the Pact expressly acknowledges the right of the Parties to make reservations.

A direct consequence of the Pact is the termination of the validity of a series of treaties as enunciated by its Article LVIII:

- Treaty to Avoid or Prevent Conflicts between the American States (May 3, 1923);

- General Convention of Inter-American Conciliation (January 5, 1929);

- General Treaty of Inter-American Arbitration and Additional Protocol of Progressive Arbitration (January 5, 1929);

- Additional Protocol to the General Convention of Inter-American Conciliation (December 26, 1933);

- Anti-War Treaty of Non-Aggression and Conciliation (October 10, 1933);

- Convention to Coordinate, Extend and Assure the Fulfillment of the Existing Treaties between the American States (December 23, 1936);

- Inter-American Treaty on Good Offices and Mediation (December 23, 1936);

- Treaty on the Prevention of Controversies (December 23, 1936).

None of these treaties granted jurisdiction to the Permanent Court of International Justice. Although the Pact is a treaty historically associated with the Organization of American States and corresponds to the

jurisdiction in accordance with Article $\mathrm{V}$ are contrary to Argentine tradition. The protection of aliens, who in the Argentine Republic are protected by its Supreme Law to the same extent as the nationals, is also contrary to that tradition". Signatories and Ratifications, Pact of Bogota. Available at: http://www.oas.org/juridico/english/sigs/a-42.html\#Argentina 12 In 1987, Venezuela spoke in favor of the voluntary jurisdiction of the Court and of recourse to it by means of an optional clause. Consejo Permanente de la Organización de los Estados Americanos. Comisión de Asuntos Jurídicos y Políticos, OEA/Ser. G. CP/ CAjP-663/87. 19 marzo 1987, Observaciones de los Gobiernos de los Estados Miembros al Nuevo Tratado Americano de Soluciones Pacíficas (AG/RES.821 (XVI-0/86), pp. 4-5.

13 C. G. Fenwick, "The Revision of the Pact of Bogota", American Journal of International Law, 48, 1954, p. 124. 
provisions of Article 23 of that organization's Charter, its structure and functioning is autonomous from any other treaty. ${ }^{14}$ The Pact is the most comprehensive treaty for dispute settlement in the American hemisphere, but it is not the only source asserting the compulsory jurisdiction of the International Court of Justice. Some members of the OAs have accepted the compulsory jurisdiction of the Court under article 36, 2 of the Statute. ${ }^{15}$

For the establishment of a Permanent Court of International Justice and its successor, the International Court of Justice and the role of Latin American states, reference should be made to the study of J. J. Quintana, ${ }^{16}$ which thoroughly describes the statute and Chapter XIV of the Charter. It is clear that Articles 37, 38, and 94 of the Statute owe much to initiatives of Latin American countries, and that the jurisdiction of the ICJ was a matter of interest for all of them.

The characteristics of the Pact of Bogota as an instrument for the settlement of disputes may be systematized as follows:

- The Pact contains a complete set of mechanisms raging from diplomatic means including conciliation, to adjudication through judicial and arbitral procedures;

- It establishes a complex relationship between recourse to the International Court of Justice, the competence of the Court, and arbitration, whereas the latter may be available in case the ICJ declares itself to be without jurisdiction in controversies other than those set out in Articles V, VI and VII of the Treaty (Article XXXV). Thus, the "High Contracting Parties obligate themselves to submit [a dispute] to arbitration, in accordance with the provisions of Chapter Five of this Treaty". ${ }^{17}$

14 J. J. Quintana, "The Latin American Contribution to International Adjudication: the Case of the International Court of Justice”, 1992, 39 Netherlands Law Review, pp. 127-154. Also, X. Fuentes, "Latin American States and the International Court of Justice", in Litigating International Law Disputes, ed. by N. Klein, Cambridge: Cambridge University Press, 2014, pp. 79-105.

15 Costa Rica, Dominica (Commonwealth of), Dominican Republic, Haiti, Mexico, Nicaragua, Panama, Paraguay, Peru and Uruguay.

16 Quintana, op. cit., pp. 130-131.

17 This formula was rejected by the United States, which entered a reservation to the effect that the submission to arbitration should be dependent upon the conclusion of 
- It lists a number of conditionalities that establish limits to the competence and admissibility of cases before international tribunals as well to other mechanisms of dispute settlement.

- It allows for reservations by the parties with the result that they can be subject to different mechanisms or obligations with respect to each and every other party.

\section{The structure of the Pact: a test for legal logic}

The test starts with Article II that says that

The High Contracting Parties recognize the obligation to settle international controversies by regional procedures before referring them to the Security Council of the United Nations.

Consequently, in the event that a controversy arises between two or more signatory states which, in the opinion of the parties, cannot be settled by direct negotiations through the usual diplomatic channels, the parties bind themselves to use the procedures established in the present Treaty, in the manner and under the conditions provided for in the following articles, or, alternatively, such special procedures as, in their opinion, will permit them to arrive at a solution.

In the past, there has been discussion of just how critical Article II is for determining the admissibility of a case. First of all, the clause entails a treaty interpretation issue where the question is whether it is mandatory to exhaust regional mechanisms and how to determine whether those mechanisms have failed before moving toward a more general or universal procedure.

The second point posed by Article II, mainly due to problems arising from the use of different languages, is whether the opinions of the two parties must be taken into account, or just the opinion expressed by one of them.

This question arose in a case involving Nicaragua and Honduras, ${ }^{18}$ where it was decided that the views of both parties should be taken into

a special agreement between the parties to a case. Signatories and Ratifications, Pact of Bogota. Available at: http://www.oas.org/juridico/english/sigs/a-42.html\#United States 18 Border and Transborder Armed Action (Nicaragua v. Honduras), Jurisdiction and Admissibility, Judgement, ICJ, Reports 1988, pp. 94-96, paras. 63-67. 
account. It should be remembered that in this case the negotiators were mostly from Spanish-speaking countries and what was said was in Spanish. The Court has followed this approach which "presupposes that the holding of opinions can be subject to demonstration", and that the Court may expect "the Parties [to provide] substantive evidence that they consider in good faith", and to consider whether or not a certain possibility of negotiation exists. It is an invitation for the Court "to seek evidence of the Parties' 'genuine intentions", ${ }^{19}$ and the exercise of the judicial function would depend on the determination of that question on the basis of available evidence.

This issue came into the open when the Inter-American Juridical Committee analyzed possible amendments to the Pact and the proposal to change the above-mentioned phrase to "in the opinion of one of the Parties", which explicitly favored a different interpretation. But this change was not approved. ${ }^{20}$ States have addressed the particulars of Article II in order to favor a broader scope for the clause. In 1973, for example, Ecuador suggested adding the word "just" to the search of solutions to disputes. ${ }^{21}$

This approach differs slightly from the language of Article 26 of the OAS Charter, where it is said that when one of the parties in a dispute between two or more American states believes that the dispute cannot be settled through usual diplomatic channels, the parties shall agree on a method of settlement. In real terms, this clause does not grant powers to the Organization to determine the existence of a dispute or to impose a method on the parties. The ambit of these provisions is further developed in the clauses dealing with the good offices of the Permanent Council under Articles 84 and 85 of the Charter.

The situation described above also differs from the idea that it is for a tribunal to assert the existence of a dispute through admissibility proceedings in accordance with a given treaty. It may be recalled that the

\footnotetext{
19 Ibid., pp. 94-95, para. 65.

20 CJI/RES.II-13/1985. "Dictamen examen del Tratado de Soluciones Pacíficas ('Pacto de Bogotá') tomando en cuenta las reservas que le han formulado los Estados signatarios del mismo, así como las razones que podrían tener algunos Estados para no ratificarlo a fin de determinar si, para asegurar su viabilidad, se requiere formular reformas a dicho instrumento", pp. 22-23.

21 Organización de los Estados Americanos, Comisión Especial para Estudiar el Sistema Interamericano y Proponer Medidas para su Reestructuración. OEA/Ser.P CEESI/doc.26/73. Vol. IV Parte 2, 8 noviembre 1973, pp. 201-206.
} 
ICJ has had to issue a ruling with respect to the assertion by one party that a dispute exists with another party. The ICJ decided that an assertion is not sufficient to prove the existence of a dispute, nor does the mere denial of a dispute prove its non-existence. ${ }^{22}$

Article IV establishes another characteristic of the system when it says that "Once any pacific procedure has been initiated, whether by agreement between the parties or in fulfillment of the present Treaty or a previous pact, no other procedure may be commenced until that procedure is concluded". This clause provides grounds to sustain the inadmissibility of a claim whenever there is a procedure in course on the same matter and one of the parties would prefer it to be subject to another procedure, including judicial recourse.

This question was discussed in the jurisdiction/admissibility phase of the Border and Transborder Armed Actions case (Nicaragua v. Honduras), submitted by Nicaragua simultaneously with a lawsuit against Costa Rica in $1986 .{ }^{23}$ Honduras contended that a "special procedure" (the Contadora process) was in place and that according to Article IV of the Pact of Bogota, and "elementary considerations of good faith," Nicaragua was precluded from commencing any other procedure for a peaceful settlement until such time as the said (Contadora) process had been concluded. Honduras argued that that time had not yet arrived. ${ }^{24}$

Neither Article II nor Article IV were found to bar the jurisdiction of the Court, which concluded that there were grounds to believe that negotiations that may have been active at the time of Nicaragua's application to the Court were then at a standstill. The Court affirmed that the Contadora process did not meet the conditions for negotiations laid down in Article II of the Pact, ${ }^{25}$ and that at the time of Nicaragua's filing of its application (28 July 1986), the process was concluded within

22 The existence of a dispute is a matter for objective determination, the Court has said. Interpretation of Peace Treaties with Bulgaria, Hungary and Romania, First Phase, Advisory Opinion, ICJ Reports 1950, p. 74.

23 Border and Transborder Armed Actions (Nicaragua v. Costa Rica) ICJ Reports 1986. Discontinued in 1987.

24 The Contadora process was defined as a combination of consultation, mediation, and negotiation of a broader subject that had to deal with peace and security in the subregion and the settlement of the crisis among Central American states.

25 "Furthermore", said the Court, "no other negotiation which would meet the conditions laid down in that text was contemplated on 28 July 1986, the date of filing of the 
the meaning of Article IV, and neither was it admissible to consider it a special procedure. ${ }^{26}$

\section{The structure of compulsory jurisdiction under the Pact of Bogota}

The Pact of Bogota is one of the treaties establishing the competence of the Court following the language of Article 36, 2 of the Statute of the ICJ. It allows for state parties to declare, "unconditionally or on condition of reciprocity on the part of several or certain states, or for a certain time", that they "recognize as compulsory ipso facto and without special agreement, in relation to any other state accepting the same obligation, the jurisdiction of the Court in legal disputes". The ICJ became the alternative to projects that emerged during the twentieth century and proposed the creation of permanent hemispheric tribunals. ${ }^{27}$

The Pact follows the pattern of the Statute of the ICJ, and also allows for the recourse to arbitration in a residual situation. The role of the ICJ is evident when Article XXXI begins with the words

in conformity with Article 36, paragraph 2, of the Statute of the International Court of Justice [...] the High Contracting Parties declare that they recognize, in relation to any other American State, the jurisdiction of the Court as compulsory ipso facto, without the necessity of any special agreement so long as the present Treaty is in force, in all disputes of a juridical nature that arise among them concerning:

a) The interpretation of a treaty;

b) Any question of international law;

c) The existence of any fact which, if established, would constitute the breach of an international obligation;

d) The nature or extent of the reparation to be made for the breach of an international obligation.

Nicaraguan Application", Border and Transborder Armed Action (Nicaragua v. Honduras), Jurisdiction and Admissibility, Judgment, ICJ Reports 1988, p. 99, para. 75.

26 Ibid., p. 95, para. 93.

27 M. Hudson, International Tribunals: Past and Future, Washington D.C.: Carnegie Endowment for International Peace and the Brookings Institution, 1944, pp. 173-179. 
This text, a sort of contractual expression of Article 36, 2 of the Statute of the ICJ, ${ }^{28}$ places the Pact under the provision of Article 36.1 of the said Statute, which refers to treaties and conventions in force by which States confer jurisdiction on the Court. ${ }^{29}$

The relationship between the compulsory jurisdiction of the Court and the preexistence of a conciliation procedure under Article XXXII is envisioned for cases where a conciliation procedure previously established according to the Pact or by agreement of the parties has not led to a solution, and the parties do not agree upon an arbitral procedure. In this situation, states the Pact, "either of [the parties] shall be entitled to have recourse to the International Court of Justice in the manner prescribed in Article 40 of the Statute thereof. The Court shall have compulsory jurisdiction in accordance with Article 36, paragraph 1 of the said Statute".

The discussion with respect to the grounds for compulsory jurisdiction of the ICJ in a case where the relationship between Articles XXXI and XXXII was taken into consideration was settled in the sense that the referenced Articles were separate sources of jurisdiction. ${ }^{30}$

In the judgment of the Court, the independence of the outcome of a conciliation procedure and the jurisdictional competence of the ICJ under Article XXXI had to be examined. It was affirmed that the Articles were independent one from the other and that the provision embodied in Article XXXII referring to instances when the conciliation procedure does not lead to a solution, and "the said parties have not agreed upon an arbitral procedure", implied that either party is entitled to recourse to the ICJ in the manner prescribed in Article 40 of the Statute. Therefore, Article XXXII did not render the jurisdiction of the ICJ subordinate to the failure of a conciliation procedure and the operation of the jurisdictional

28 E. Jiménez de Aréchaga, "The Compulsory Jurisdiction of the International Court of Justice under the Pact of Bogota and the Optional Clause", International Law at a time of perplexity, Essays in Honor of Shabtai Rosenne, in Y. Dinstein editor, Dordrecht: Martinus Nijhoff Publishers, 1988, p. 356.

29 See the European Convention for the Peaceful Settlement of Disputes. 1957; http:// conventions.coe.int/Treaty/EN/Treaties/Html/023.htm; Revised General Act for the Pacific Settlement of International Disputes, 1949; United Nations, Treaty Series, vol. 71, p. 101.

$30 \quad$ Border and Transborder Armed Action (Nicaragua v. Honduras), Jurisdiction and Admissibility, Judgment, ICJ, Reports 1988, pp. 89-90, paras. 47-48. A parallel submission by Nicaragua against Costa Rica in the same year, on analogous bases, was later discontinued. In the latter case, Costa Rica did not challenge the jurisdiction of the Court. 
clause of the ICJ under Article XXXI is not dependent upon a conciliation procedure previously undertaken.

Proposals had been made shortly before, in $1985,{ }^{31}$ by the InterAmerican Juridical Committee to amend Article XXXII and render recourse to the ICJ subject to the previous agreement of parties whenever they failed to reach agreement after the completion of a conciliation procedure. These proposals were not taken up by the Parties to the Pact of Bogota.

From a historical perspective, these clauses are to be analyzed in the light of a difference of opinion between those in favor of granting compulsory universal jurisdiction for interstate disputes, and those who held other views more inclined toward attributing compulsory jurisdiction to the Court subject to the express consent of the states concerned, with the right to set up limits and exceptions. This debate has recurred throughout the life of the OAS.

The case of Nicaragua v. Honduras (1986-1988) gave rise to another discussion around two points related to the application of the Pact in light of Article XXXI. This discussion entailed, first, whether the application of this provision had to be supplemented by a declaration, rendering ineffective the application of Article XXXI if it was not followed by the referenced declaration, and second, whether this Article entailed a collective acceptance of the compulsory jurisdiction of the Court. ${ }^{32}$ In 1988, the Court did not uphold the first assertion. With respect to the second, it affirmed that Article XXXI could be amended by the rules of the Pact itself, but not by unilateral declarations of the Parties. A reservation made by the United States, not party to the Pact, reflects this question. ${ }^{33}$

31 Comité Jurídico Interamericano. "Examen del Tratado Americano de Soluciones Pacíficas (Pacto de Bogotá), tomando en cuenta las reservas que le han formulado los Estados signatarios del mismo, así como las razones que podrían tener algunos Estados para no ratificarlo a fin de determinar si, para asegurar su viabilidad, se requiere formular reformas a dicho instrumento", pp. 28-30.

32 Border and Transborder Armed Action (Nicaragua v. Honduras), Jurisdiction and Admissibility, Judgment, ICJ, Reports 1988, p. 84, paras. $32-33$ and p. 88, para. 41.

33 The United States declared that "The acceptance by the United States of the jurisdiction of the International Court of Justice as compulsory ipso facto and without special agreement, as provided in this Treaty, is limited by any jurisdictional or other limitations contained in any Declaration deposited by the United States under Article 36, paragraph 4 , of the Statute of the Court, and in force at the time of the submission of any case". Signatories and Ratifications, Pact of Bogota. Available at: http://www.oas.org/juridico/ english/sigs/a-42.html\#United States 
Faced with two titles to jurisdiction, on other matters the Court may have to decide whether to proceed from the particular (Pact of Bogota) to the more general title (optional declaration). The Court has issued two affirmations in this respect, first that the Pact of Bogota does not necessarily prevail over and exclude a second title of jurisdiction (the optional clause declarations) and second, that the commitment under Article XXXI does not depend upon the existence of an optional declaration on the same matter. As the Court has said, it is within its competence to "ascertain whether an intention on the part of the Parties exists to confer jurisdiction upon it". ${ }^{34}$ In the Nicaragua v. Honduras case, where Nicaragua stated that the competence of the Court was based on

[...] the Honduran Declaration dated 20 February 1960 accepting the jurisdiction of the Court in conformity with the provisions of Article 36, paragraph 2, of the Statute of the Court; or (in case the Declaration of 1960 has been validly modified) the Honduran Declaration of 1960 as modified by the Declaration dated 22 May 1986, and the Nicaraguan Declaration dated 24 September 1929; and/or by virtue of the provisions of Article XXXI of the Pact of Bogota and Article 36, paragraph 1, of the Statute of the Court,

the Court fully acknowledged Article XXXI of the Pact.

Honduras contended that the jurisdiction of the Court had to be ascertained in accordance with Article XXXI of the Pact, but that this clause could be supplemented by means of unilateral declarations by each party to the Pact as provided for in Article 36, paragraph 2 of the Statute; it followed that the jurisdiction of the Court was to be subject to the terms in which it had been acknowledged by the unilateral declarations of the parties. According to this reasoning, the extent of the jurisdiction of the Court depended on whatever reservations a state party may have introduced to its unilateral declaration of acceptance of the Court's jurisdiction.

Based on the history of the Pact and the interpretation of its provisions, the Court did not uphold this interpretation and decided that Article XXXI was independent of unilateral declarations of acceptance of the Court's jurisdiction: "The commitment in Article XXXI [...] is an

34 Border and Transborder Armed Actions (Nicaragua v. Honduras), Jurisdiction and Admissibility, Judgment, ICJ Reports 1988, p. 76, para.16 in fine. 
autonomous commitment, independent of any other which the parties may have undertaken or may undertake by depositing with the United Nations Secretary General a declaration of acceptance of compulsory jurisdiction under Article 36, paragraphs 2 and 4 of the Statute". 35

The exclusiveness of the jurisdictional system of the Pact vis-à-vis other means of establishing the jurisdiction of the Court was again questioned in a Territorial and Maritime Dispute, Nicaragua v. Colombia. ${ }^{36}$ In this case, in which the Court adjudicated sovereignty over islands (the entitlement and composition of the archipelago of San Andrés, including some maritime features and a maritime delimitation), the Court was called to decide whether the declarations made by the Parties under the optional clause (article 36, 2 of the Statute) could provide "a distinct and sufficient basis of jurisdiction" as Nicaragua asserted, irrespective of the application of the Pact of Bogota and the operation of the exception contained in Article VI of the Pact.

This means that if declarations by the Parties under the optional clause were in force, they could provide a basis for the Court's jurisdiction over all matters disputed in the application and within the scope of said declarations. Thus, were the Pact of Bogota insufficient to provide for jurisdiction with respect to a particular matter, the same question could come up before the Court under concordant optional declarations. Confronted with just such a situation in the Nicaragua v. Colombia case of 2007, the ICJ refined this approach and stated that since its jurisdiction to deal with all the other aspects of the dispute had been asserted on the basis of Article XXXI of the Pact, there was no reason to examine the optional clause. ${ }^{37}$

35 Border and Transborder Armed Actions (Nicaragua v. Honduras), Jurisdiction and Admissibility, Judgment, ICJ Reports 1988, p. 82, para. 36.

36 Territorial and Maritime Dispute (Nicaragua v. Colombia), Preliminary Objections, Judgment, ICJ Reports 2007.

37 Ibid., p. 872, para. 132. "[...] Having first examined the preliminary objection raised by Colombia to jurisdiction under the Pact of Bogota, the Court has concluded above (paragraphs 97, 104 and 120) that it has jurisdiction on the basis of Article XXXI of the Pact to deal with all the other aspects of the dispute. Consequently, no purpose is served by examining whether, in relation to those aspects, the declarations of the Parties under the optional clause could also provide a basis of the Court's jurisdiction — see Border and Transborder Armed Actions (Nicaragua v. Honduras), Jurisdiction and Admissibility, Judgment, ICJ Reports 1988, p. 90, para. 48-”. 


\section{Restrictions and Reservations to the Pact of Bogota: different sources, same consequences}

Although the Pact displays ample confidence in the Court, it significantly confirms several restrictions on the competence of the tribunal. Thus, when the Court declares itself to be without jurisdiction to hear a controversy by virtue of Articles V, VI and VII of the Pact, that controversy shall be declared ended, as set forth in Article XXXIV. It must also be taken into account that in accordance with Article IV, "Once any pacific procedure has been initiated, whether by agreement between the parties or in fulfillment of the present Treaty or a previous pact, no other procedure may be commenced until that procedure is concluded".

The applicability of such clauses was corroborated by the Court in its decision in the case of Border and Transborder Armed Actions (Nicaragua/Honduras), Jurisdiction, and Admissibility, in which the Court stated:

'Moreover, some provisions of the Treaty restrict the scope of the parties' commitment. Article V specifies that procedures under the Pact "may not be applied to matters which, by their nature, are within the domestic jurisdiction of the State". Article VI provides that they will likewise not apply "to matters already settled by arrangement between the parties, or by arbitral award or by decision of an international court, or which are governed by agreements or treaties in force on the date of the conclusion of the present Treaty".

Similarly, Article VII lays down specific rules relating to diplomatic protection. $^{38}$

The above-mentioned Articles set out the following:

Article 5: The aforesaid procedures [regulated by the Pact] may not be applied to matters which, by their nature, are within the domestic jurisdiction of the state. If the parties are not in agreement as to whether the controversy concerns a matter of domestic jurisdiction, this preliminary question shall be submitted to decision by the International Court of Justice, at the request of any of the parties. ${ }^{39}$

38 Border and Transborder Armed Actions (Nicaragua v. Honduras), Jurisdiction and Admissibility, Judgment, ICJ Reports 1988, pp. 84-85, p. 35.

39 This clause has not been discussed before the Court up to this time. 
Article 6: The aforesaid procedures, furthermore, may not be applied to matters already settled by arrangement between the parties, or by arbitral award or by decision of an international court, or which are governed by agreements or treaties in force on the date of the conclusion of the present Treaty.

Article 7: The High Contracting Parties bind themselves not to make diplomatic representations in order to protect their nationals, or to refer a controversy to a court of international jurisdiction for that purpose, when the said nationals have had available the means to place their case before competent domestic courts of the respective state.

Article VI poses a crucial test to the functioning of the Pact. It was introduced into the Pact following an initiative by Peru after a substantive discussion about its intent. As the Peruvian delegate stated in 1948, "[...] the article must establish the principle according to which the procedures (under the Pact) do not apply to matters that have been resolved by an agreement of the parties, by an arbitral award, or by the decision of a tribunal. It is obvious that if difficulties arise in the proceedings, certainly the same arbitrator, in accordance with the General Treaty on Arbitration, can resolve them. The doubt is perfectly resolved since the article adds 'or which are governed by agreements or treaties in force on the date of the conclusion of the present 'Treaty'; because those 'treaties in force' generally indicate how to resolve those matters. It would be very dangerous", the delegate continued, "to attenuate the formula. In the first place, it would be very difficult to attenuate it; secondly, it would open the door to provoking a dispute, which is exactly what we want to avoid". ${ }^{40}$

In the midst of a 1970's re-evaluation of the Inter-American System, it was acknowledged that this article guaranteed the principles of pacta sunt servanda and res judicata, but Ecuador sought to qualify the rule with exemptions referring to the validity or de facto unenforceability of a treaty, the interpretation or revision of an award, or the interpretation of a decision. ${ }^{41}$ These exemptions were not upheld by the Special Commission set out by the OAS to restructure the System.

40 Minutes of the Third Session of the Third Commission of the Ninth Inter-American Conference, 27 April 1948, p. 135. Ministerio de Relaciones Exteriores de Colombia, Novena Conferencia Internacional Americana, Actas y Documentos, Vol. IV, 1953, pp. 132-136.

${ }^{41}$ Reformas que propone la Delegación del Ecuador al Pacto de Bogotá y a la Carta de 
Reservations made by some states upon signing or ratifying the Pact shed light on the substance of the referred provision. In a study conducted by the General Secretariat of the OAS in 1985, it was said that some of the reservations to Article VI (expressed by Bolivia and Ecuador) were "equal to depriving such acts (treaties, arrangements, awards or decisions) from their legal effectiveness if faced with the possibility that already settled disputes might be reopened". ${ }^{42}$

Upon signing, Bolivia declared that "The Delegation of Bolivia makes a reservation with regard to Article VI, in as much as it considers that pacific procedures may also be applied to controversies arising from matters settled by arrangement between the Parties, when the said arrangement affects the vital interests of a state". The reservation was confirmed at the time of the Pact's ratification in 2011. Chile objected to the reservation and stated that the Pact was not in force between the two countries. ${ }^{43}$

Peru's reservation to Article VI also confirmed the jurisdictional character of the Article's content: "Reservation with regard to Article XXXIII and the pertinent part of Article XXXIV, inasmuch as it considers that the exceptions of res judicata, resolved by settlement between the parties or governed by agreements and treaties in force, determine, by virtue of their objective and peremptory nature, the exclusion of these cases from the application of any procedure". Peru clearly purported to exclude the rule according to which the Court decides on its own competence. In 2006, Peru withdrew this reservation while preparing a submission against Chile, ${ }^{44}$ and Bolivia did the same in 2013. ${ }^{45}$

la OEA. Organización de los Estados Americanos. CEESI, OEA/Ser.P. CEESI/Subcom.I/ doc.30/73 corr.1. 24 de octubre 1973. Also see Exposición del Presidente de la Delegación del Ecuador, Embajador Galo Leoro F., para fundamentar el Proyecto de reformas al Pacto de Bogotá y a la Carta de la OEA, en materia de solución de controversias. CEESI, OEA/Ser.P. CEESI/Subcom.I/doc.31/73, 23 de octubre 1973, pp. 207-208. G. Leoro reiterated these ideas in "La reforma del Tratado Americano de Soluciones Pacíficas o Pacto de Bogotá", Anuario Jurídico Interamericano, 1981, pp. 68-69.

42 Organization of American States, Permanent Council, OEA/Ser.G CP/doc.1560/85 (Part II), 9 April 1985. Original Spanish, pp. 17-18.

43 Signatories and Ratifications, Pact of Bogota. Available at: http://www.oas.org/ dil/a-42_objection_chile_06-15-2011.pdf

44 Signatories and Ratifications, Pact of Bogota. Available at: http://www.oas.org/juridico/english/sigs/a-42.html\#Perú

45 Signatories and Ratifications, Pact of Bogota. Available at: http://www.oas.org/dil/ esp/Nota\%20de\%20Bolivia.\%20ND-039-13.pdf 
Article XXXIII of the Pact refers to the hypothesis of a disagreement between the parties as to the jurisdiction of the Court, a matter that will have to be decided by the Court itself ("the Court itself shall first decide that question").

In conjunction with Articles V and VII, the decisive nature of Article VI is confirmed in Article XXXIV of the Pact, which states that "If the Court, for the reasons set forth in Articles V, VI and VII of this Treaty, declares itself to be without jurisdiction to hear a controversy, that controversy shall be declared ended".

These two issues relate to the procedural stages; on one hand the competence of the tribunal to rule on its own competence, and on the other, the consequences of a Court decision in this sphere. Both subjects entail significant factors for understanding the legal texture of the Pact and have been the backdrop of the Pact for more than 30 years, as evidenced by concrete practice.

To help understand the perspective of this article, note that the idea that a treaty for the settlement of disputes "does not affect" or "is without effect for" previous undertakings by the Parties was already embodied in some Inter-American treaties for the settlement of disputes. ${ }^{46}$ Likewise, Article 90 of the OAS Charter as amended in 1985 states that "In performing their functions with respect to the peaceful settlement of disputes, the Permanent Council and the respective ad hoc committee shall observe the provisions of the Charter and the principles and standards of international law, as well as take into account the existence of treaties in force between the parties". ${ }^{47}$

46 Article IV of the Treaty on the Prevention of Controversies, of 1936. www.oas.org/ english/sigs/b-16.htm. The same concept was already present in Article VI of the InterAmerican Treaty on Good Offices and Mediation (1936): "The present Treaty shall not affect obligations previously entered into by the High Contracting Parties by virtue of international agreements". www.loc.gov/law/help/us-treaties/bevans/m-ust000003-0362. pdf

47 Upon signing the Protocol of Amendment of the OAS Charter (1985), Peru stated that it was only an initial, albeit significant, step in the process of restructuring the InterAmerican system, as provided for in resolution AG/RES. 745 (XIV-0/84):

"The Delegation of Peru states by way of a reservation that the powers conferred upon the Secretary General in Article 116 may not be exercised for matters that have already been resolved through settlement by the parties or through the decision of an arbitrator or a judgment handed down by an international court, or that are governed by agreements or treaties in force. Also, in accordance with international law, good offices are a means of 
In the case between Peru v. Chile decided by the ICJ in 2014, Chile also made the argument that the Court had to apply Article VI to Peru's allegation regarding the land boundary between the countries, as agreed in a 1929 Treaty and fully determined and demarcated in 1930, well before $1948 .{ }^{48}$

The 13 December 2007 Judgment of the Court closing the preliminary objections phase in the Nicaragua v. Colombia case concerning their territorial and maritime boundary illustrates the jurisdictional system of the Pact, in keeping with the terms used by the tribunal. ${ }^{49}$ In this case, provisions contained in Articles VI and XXXIV were invoked by Colombia to challenge the jurisdiction of the Court. In essence, Colombia contended that the Court lacked jurisdiction to decide the case by virtue of Article VI in the sense that the dispute was settled by the 1928 Treaty and a 1930 Protocol known as the Esguerra-Bárcenas Treaty, in force in 1948. Nicaragua, on the other hand, claimed that the 1928 Treaty was invalid, or alternatively, had been terminated due to a material breach by Colombia.

So the determination of the jurisdiction of the Court with respect to matters "settled" or "governed by agreements or treaties in force on the date of the conclusion of the Treaty" was at the core of the interpretation of Article VI in this case. The 2007 judgment followed the approach under which "the clear purpose of this provision was to preclude the possibility of using those procedures, and in particular judicial remedies, in order to reopen such matters as were settled between the parties to the Pact, because they had been the object of an international judicial decision or a treaty". ${ }^{0}$

peaceful settlement whose scope has been specified in international treaties, including the Pact of Bogota. This procedure assumes the consent of the parties, and it is in this sense that the Delegation of Peru understands the powers conferred upon the Permanent Council in the new Article 84 of this Protocol". http://www.oas.org/dil/treaties_A-50_Protocol_of_Cartagena_de_Indias_sign.htm\#Peru (accessed 1 May 2015).

48 Counter-Memorial of the Government of Chile, Vol. I, para. 1,71.

49 J. J. Quintana, "La impugnación de la competencia en asuntos contenciosos ante la Corte Internacional de Justicia", ACDI, 2008, 1, pp. 12-48. Available at: http:/ /www.anuariocdi.org/anuario-capitulos-pdf/4_Quintana.pdf; R. Nieto Navia, "La decisión de la Corte Internacional de Justicia sobre excepciones preliminares en el caso de Nicaragua v. Colombia", ACDI, 2009, 2, pp. 11-57. Available at: http://www.anuariocdi.org/anuario2capitulos-pdf/1_la_decision_navia.pdf

50 Territorial and Maritime Dispute (Nicaragua v. Colombia), Preliminary Objections, Judgment, ICJ Reports 2007, p. 858, para. 77. 
Whether the matters raised by Nicaragua were already "settled" at the time of adoption of the Pact (defined by the Court as 1948) was then subject to determination. The Court found that on the face of the text of Article I of the Treaty, the matter of sovereignty over the islands of San Andrés, Providencia, and Santa Catalina had been settled by virtue of the 1928 Treaty "within the meaning of Article VI of the Pact of Bogota". On this basis, the Court found no need to further consider any aspect of the Treaty to reach the conclusion that there was nothing relating to this issue "that could be ascertained only on the merits". ${ }^{51}$

The Court also found that the Treaty did not provide the answer to the question as to which maritime features apart from the islands of San Andrés, Providencia, and Santa Catalina formed part of the San Andrés Archipelago over which Colombia had sovereignty. On the other hand, the features of Roncador, Quitasueño, and Serrana were subject to a dispute of sovereignty between Colombia and the United States of America, as the Treaty indicated. In addition, the Court ruled, the maritime delimitation was not settled by the Treaty.

Consequently, after examining the arguments and materials presented by the Parties, the Court concluded that it had jurisdiction under Article XXXI of the Pact to entertain the dispute concerning maritime delimitation. ${ }^{52}$ It is notable that the Court used the term "settled" to simplify the reference to the term "settled" and the formulation "governed by agreements or treaties in force on the date of the conclusion of the present Treaty", both employed in Article VI, in light of the specific circumstances of the case, where no distinction as to legal effect was to be drawn between them. (Para. 39 in fine).

The subtle distinction between "settled" and "governed by agreements or treaties in force on the date of the conclusion of the present Treaty" is relevant whenever there is a question about whether a matter is governed by a treaty negotiated irrespective of the existence of a dispute, or if it has been settled by a third party decision, concluding a dispute settlement procedure conducive to a binding award. One author advances the thesis that the Pact is not to reopen differences already settled and is intended to protect treaties from revisionist tendencies. ${ }^{53}$

51 Ibid., p. 861, para. 88.

52 Ibid., p. 869, para 120.

53 Luis García-Corrochano makes explicit reference to Ecuador's views before the 1998 
The underlying question is whether there is a need to determine either that Article VI only operative when a dispute has been settled through a treaty or by an award or a judicial decision, or as appears more aligned with the text and the intention of the Parties, Article VI covers all situations, including but not limited to former disputes either governed or settled through the application of other international instruments. This was part of the allegation submitted by Bolivia against Chile's preliminary objection to the Court's jurisdiction, ${ }^{54}$ invoking Article VI of the Pact of Bogota. Chile's argument is that the case lodged by Bolivia conceals the revision of the Peace and Amity Treaty of 1904, and that Article VI excludes the jurisdiction of the ICJ. ${ }^{55}$

On another issue, which is the effect of Article VI in the sphere of jurisdiction, Colombia raised arguments in its Preliminary Objections against Nicaragua's submissions in the Territorial and Maritime Dispute, favoring the thesis that the Pact was clear with respect to the object and purpose of Article VI, in the sense that the duty of the Court was to declare the dispute "ended". ${ }^{56}$ Then the question arose as to the meaning of "preliminary" in light of the facts exposed by the parties, taking into account the possibilities provided by Article 79, 1 of the Rules of the Court. At stake was whether the objection had to be decided before proceeding any further on the merits. ${ }^{57}$

In the aforementioned case, Judges Abraham, Al-Khasawneh, Bennouna, and Ranjeva were of the opinion that the objection with respect

settlement with Peru in his study "El Tratado Americano de Solución Pacífica de Controversias (Pacto de Bogotá)", Agenda Internacional, 1997. https://www.google.cl/\#q=El+T ratado + Americano + de + Soluci $\% \mathrm{C} 3 \% \mathrm{~B} 3 \mathrm{n}+\mathrm{Pac} \% \mathrm{C} 3 \% \mathrm{ADfica}+\mathrm{de}+$ Controversias + (Pact o + de + Bogot $\%$ C 3\%A1) $\% 2 \mathrm{C}+$ Agenda+Internacional $\% 2 \mathrm{C}+$ (accessed 1 May 2015).

54 According to Bolivia, only previously settled disputes are addressed by Article VI. Obligation to negotiate access to the Pacific Ocean (Bolivia v. Chile). Written Statement, 7 November 2014.

55 Chile argued that it may be that a matter was settled after being disputed by the parties or that a matter may be subject to an agreement after negotiations for the purpose of strengthening relations without that matter having been disputed. Obligation to negotiate access to the Pacific Ocean (Bolivia v. Chile), Preliminary Objection of the Republic of Chile, 15 July 2015.

56 Territorial and Maritime Dispute (Nicaragua v. Colombia). Preliminary Objections of the Government of Colombia, Vol. I, July 2003, pp. 76-83, paras. 2.9-2.23.

$57 \mathrm{H}$. Thirlway, The Law and Procedure of the International Court of Justice. Fifty Years of Jurisprudence, Vol. II, Oxford: Oxford University Press, 2013, pp. 1816-1824. 
to jurisdiction referred to a matter that did not have preliminary character as they considered the merits of the case. Judge Abraham considered this an effect of the unusual provision they had to deal with, which was that taken together, Articles VI and XXXIV transform a treaty in force from a question of merits to a question of jurisdiction. ${ }^{58}$ To respond to this criticism, it may be noted that the Pact does not prevent treating the question of whether one state's claim against another accords or conflicts with treaty provisions in force as a question of jurisdiction. This is a consequence of the intention of the Pact's authors as expressed in the travaux préparatoires and in Article XXXIV itself where it is said that "If the Court, for the reasons set forth in Articles V, VI and VII of this Treaty, declares itself to be without jurisdiction to hear the controversy, such controversy shall be declared ended".

\section{Jurisdiction and Compliance}

Compliance and post-adjudicative enforcement jurisdiction, or a monitoring jurisdiction of the ICJ under the Pact of Bogota, constitute another topic to highlight. ${ }^{59}$ This issue is currently under proceedings before the Court after the application of Nicaragua against Colombia in 2013 entitled "Alleged Violations of Sovereign Rights and Maritime Spaces in the Caribbean Sea". ${ }^{60}$ The point is whether the Court retains an inherent jurisdiction over the implementation or execution of a judgment or for ensuring its compliance. ${ }^{61}$ Unless the contrary was agreed, is it a separate controversy to be defined in accordance with the law of the Charter, the Statute, and the Pact of Bogota?

58 Territorial and Maritime Dispute (Nicaragua v. Colombia), Preliminary Objections, Judgment, ICJ Reports 2007. Separate Opinion of Judge Abraham, p. 905, para. 7.

59 On compliance and implementation of judicial decisions see L. Boisson de Chazournes \& A. Angelini, "Between Saying and Doing: the Diplomatic Means to Implement the International Court of Justice's Iuris Dictum", in Diplomatic and Judicial Means of Dispute Settlement, edited by L. Boisson de Chazournes, M. G. Kohen, J. E. Viñuales, Leiden, Martinus Nijhoff, 2013, pp. 155-185.

60 http://www.icj-cij.org/docket/files/155/17978.pdf

61 A. Pillepich, "Article 94", in J. P. Cot \& A. Pellet (eds.), La Charte des Nations Unies, Commentaire par article, Vol. II, $3^{\mathrm{e}}$ ed., Paris: Economica, 2005, p. 1993. Also see K. Oellers Frahm, Article 94, in B. Simma, De Khan, G Norte, and A Paulus. (eds.), The Charter of the United Nations (Third Edition), Oxford: Oxford University Press, 2012, p. 1961. 
For the continuation of the exercise of jurisdiction, the interplay between Article 60 of the Statute and the Pact of Bogota must come into operation. Apart from situations arising from an agreement or a decision of the Court itself reserving its jurisdiction in cases where there has been non-compliance by a party, are there situations in which the Court may retain inherent jurisdiction? So far, the Court does not seem to have stated that is has jurisdiction to oversee the execution of its decisions. ${ }^{62}$ On the other hand, the Nuclear Test cases show that the concept of "inherent powers" has been used in a concise manner, "to ensure that the exercise of its jurisdiction over the merits, if and when established, shall not be frustrated, and also to provide for the orderly settlement of all matters in dispute, to ensure the observance of the inherent limitations on the exercise of the judicial function' of the Court, and to 'maintain its judicial character". ${ }^{63}$ Show that the concept of "inherent powers" has been used in a concise manner, "to ensure that the exercise of its jurisdiction over the merits, if and when established, shall not be frustrated, and on the other, to provide for the orderly settlement of all matters in dispute, to ensure the observance of the "inherent limitations on the exercise of the judicial function' of the Court, and to 'maintain its judicial character".

The particulars of this issue may be aligned with Article 60 of the ICJ Statute, establishing that the judgment is final and without appeal, and that in the event of any dispute as to the meaning or scope of the judgment, the Court shall construe it upon the request of any party. The key phrase here is "dispute as to the meaning and scope of the judgment", which may not be apply to non-compliance. There is also the question of the freedom of the parties, after the conclusion of adjudicatory proceedings, to undertake negotiations that do not purport to derogate the effect of res judicata of a given judicial decision. ${ }^{64}$

Article on denunciation poses other questions with respect to ICJ jurisdiction. It is structured in two paragraphs:

62 G. Guillaume, "De l'exécution des décisions de la Cour internationale de Justice" (1997), in La Cour internationale de justice à l'aube du XXIe siècle, Le regard d'un juge, Paris: Éditions A. Pedone, 2003, pp. 178-179.

63 Nuclear Tests (New Zealand v. France), Judgment, ICJ Reports 1974, p. 463, para. 23; Nuclear Tests (Australia v. France), Judgment, ICJ Reports 1974, p. 259, para. 23.

${ }^{64} \mathrm{~K}$. Wellens, Negotiations in the Case Law of the International Court of Justice, Farnham: Ashgate, 2014, pp. 292-293. 
The present Treaty shall remain in force indefinitely, but may be denounced upon one year's notice, at the end of which period it shall cease to be in force with respect to the state denouncing it, but shall continue in force for the remaining signatories. The denunciation shall be addressed to the Pan American Union, which shall transmit it to the other Contracting Parties.

The denunciation shall have no effect with respect to pending procedures initiated prior to the transmission of the particular notification.

According to the principles on interpretation of treaties as embodied in the Vienna Convention on the Law of Treaties, is it plausible to sustain that the second paragraph must be understood as qualifying the effect of the first paragraph to the effect that no new procedures may be initiated during the period in question? Or is it just a provision to clarify the status of proceedings initiated prior to the transmission of the denunciation in the sense that proceedings already initiated would or would not be affected if they were subject to questioning?

This too, was subject to recent decisions on the Preliminary Objection raised by Colombia in the case lodged by Nicaragua in 2014 entitled Question of the Delimitation of the Continental Shelf between Nicaragua and Colombia beyond 200 Nautical Miles from the Nicaraguan Coast (Nicaragua v. Colombia) ${ }^{65}$ and in the case entitled Alleged Violations of Sovereign Rights and Maritime Spaces in the Caribbean Sea. ${ }^{66}$ The Court concluded that according to the applicable rules on treaty interpretation, it could not upheld the view that Article XXXI conferring jurisdiction upon the Court was not in force between the Parties on the date that the Application was filed.

\section{Discussions on the functioning of the Pact of Bogota and their bearing on the jurisdiction of the International Court of Justice}

With the perspective of time, the view of the Pact of Bogota as a useless instrument seems to have been overcome and the haste with which attempts

\footnotetext{
65 http://www.icj-cij.org/docket/files/154/18956.pdf

66 http://www.icj-cij.org/docket/files/155/18948.pdf
} 
to amend or reevaluate its provisions were once undertaken seems to be a thing of the past. $^{67}$

Initiatives such as those of $1954^{68}$ and $1971^{69}$ to study possible amendments or the drafting of a new instrument to replace the Pact of Bogota encountered opposition. In 1971, the Inter-American Juridical Committee spoke clearly in favor of maintaining the Pact in force rather than proposing amendments that would not attract general support. Subsequently, the process led by the Special Commission to Study the InterAmerican System and Propose Measures for its Restructuring (Comision Especial para Estudiar el Sistema Interamericano y Proponer Medidas para su Reestructuración - CEESI, 1972-1975), led only to an amendment of the Rio Treaty, which deals with peace and security and assistance in the interest of mutual defense. In this context, and with the failure to reach an agreement in a conciliation procedure concerning a case relevant to Article XXXII, Ecuador suggested granting the ICJ the authority to decide cases on the basis of ex aequo et bono. ${ }^{70}$

The next cycle of studies corresponds to the reform process of the OAS Charter, the 1985 adoption of the Cartagena Protocol, and the intention to review the existing mechanisms that constitute the system for dispute resolution. ${ }^{71}$

In 1984 and 1985, the Inter-American Juridical Committee devoted its work to the dispute settlement systems as embodied in the OAS Charter and related instruments, including the Pact of Bogota, providing a snapshot of

67 See Consejo Permanente de la Organización de los Estados Americanos. Comisión de Seguridad Hemisférica. Solución Pacífica de Controversias en la Organización de los Estados Americanos. Available at: http://www.oas.org/csh/spanish/ncsdoc $\% 20$ soluc $\% 20$ pacif.asp\#5 (accessed 30 May 2015).

68 Dictamen del Comité Jurídico Interamericano sobre el fortalecimiento del Sistema Interamericano de Paz, Organización de los Estados Americanos, Secretaría General, Recomendaciones e informes del Comité Jurídico Interamericano, v. X (1967/1973), Washington, 1978, p. 407. Also see Comité Jurídico Interamericano, OEA/Ser.Q/IV.3. CJI-6, trabajos realizados por el Comité Jurídico Interamericano durante el período ordinario de sesiones celebrado del 16 de agosto al 13 de septiembre de 1971. Noviembre de 1971, para. 15.

69 Ibid., para. 24.

70 Organización de los Estados Americanos, Comisión Especial para Estudiar el Sistema Interamericano y Proponer Medidas para su Reestructuración. OEA/Ser.P CEESI/doc.26/73. Vol. IV Parte 2, 8 noviembre 1973, p. 211.

71 Solución Pacífica de las Controversias en la Organización de los Estados Americanos. Available at: http://www.oas.org/csh/spanish/ncsdoc\%20soluc\%20pacif.asp 
the positions held by states at that time. In 1984, upon the requests of the General Assembly of the OAS - Resolution 745 (XIV-0/84)—, promoting the study of reforms to the main instruments of the Inter-American System, and of the Permanent Council of the Organization in respect of the Pact of Bogota, in particular, the Inter-American Juridical Committee undertook a substantive study, ${ }^{72}$ the results of which were submitted to the Permanent Council. Accordingly, a draft for a new Pact based on the provisions of the existing Pact was presented, and Colombia then submitted its own draft along the lines of the Committee's, ${ }^{73}$ but the proposed amendments were harshly criticized by eminent jurist Eduardo Jiménez de Aréchaga. ${ }^{74}$

The Committee's 1985 and 1986 projects did not seek to derogate the powers conferred to the ICJ but to introduce significant changes to conciliation and arbitration procedures, limiting their scope for action. The main changes concerned the recourse to the ICJ upon failure to reach agreement in a conciliation procedure and to limit access to the arbitral procedures to cases where the parties agreed to take this measure. In essence, these initiatives to amend the Pact of Bogota sought to grant power to the political organs of the OAS and to limit access to compulsory arbitration.

A phrase contained in the 1987 Report of the Chairman of the Informal Working Group to Study the New American Treaty of Peaceful Settlement ${ }^{75}$ reflects the situation that has prevailed up until the present:

The positions taken in the Working Group have made clear the existence of a substantive disagreement in the Organization concerning

\footnotetext{
72 CJI/RES.II-13/1985, "Dictamen examen del Tratado Americano de Soluciones Pacíficas (Pacto de Bogotá), tomando en cuenta las reservas que le han formulado los Estados signatarios del mismo, así como las razones que podrían tener algunos Estados para no ratificarlo a fin de determinar si, para asegurar su viabilidad, se requiere formular reformas a dicho instrumento".

73 Nota del Embajador Representante Permanente de Colombia en relación con el tema "Estudio del tratado especial a que se refiere el artículo 26 de la Carta de la Organización de los Estados Americanos sobre los medios adecuados para resolver las controversias y determinar los procedimientos pertinentes a cada uno de los medios pacíficos", oEA/ Ser.P, AG/doc.2030/86, $1^{\circ}$ octubre 1986, pp. 1-15.

74 "Tentativas de reforma del Pacto de Bogotá", Anuario Jurídico Interamericano, 1986, pp. 1-11.

75 Report of the Chairman of the Informal Working Group to Study the New American Treaty of Peaceful Settlement, Permanent Council of the Organization of American States, Committee on Juridical and Political Affairs. OEA/Ser.G. CP/CAjP-686/87, 27 July 1987, p. 3.
} 
the advisability of revising or replacing the Pact of Bogota. This disagreement transcends legal considerations and can only be resolved through a political agreement among the member states. Such agreement was absent at the moment of the submission of the Colombian Delegation's draft, which the General Assembly referred to the Permanent Council when it adopted resolution AG/RES.821 at its Guatemala session in November 1986.

The jurisprudence illustrates that the jurisdictional clause embodied in Article XXXI considered together with Article VI, and even Article II, have stood up over the past 15 years. With all its weaknesses and despite the criticisms directed at it, the Pact has been considered a sort of corpus juris of international law in the Americas. ${ }^{76}$

\section{Referencias}

Abello-Galvis, R., "Analyse de la Compétence de la Cour Internationale de Justice selon le Pacte de Bogotá», International Law Revista Colombiana de Derecho Internacional, 2005, 6, pp. 403-441.

Boisson de Chazournes, L. \& Angelini, A., "Between Saying and Doing: the Diplomatic Means to Implement the International Court of Justice's Iuris Dictum", in Diplomatic and Judicial Means of Dispute Settlement. Boisson de Chazournes, L, Kohen, M. G. \& Viñuales, Leiden J. E. (Eds), Martinus Nijhoff Publishers, 2013, pp. 155-185.

Connell Smith, G., The Inter American System, Londres: Oxford University Press, 1966.

Fenwick, C. G., "The revision of the Pact of Bogota", American Journal of International Law, 48, 1954, pp. 123-127.

Fuentes, X., "Latin American states and the International Court of Justice", in Litigating International Law Disputes. Klein, N. (Ed.) Cambridge University Press, 2014, pp. 79-105.

García Amador, F.V. Annotated compilation, The Inter-American System. Treaties, Conventions \& Other Documents. Vol. I, Legal - Political Affairs, London; New York: Oceana Publications, 1983.

76 Abello-Galvis, Ricardo, "Analyse de la Compétence de la Cour Internationale de Justice selon le Pacte de Bogota", International Law Review - Revista Colombiana de Derecho Internacional, 2005, 6, p. 437. 
García Corrochano, L., El Tratado Americano de Solución Pacífica de Controversias (Pacto de Bogotá), Agenda Internacional, 4, 1997, 8, pp. 51-61. https:/ / www.google.cl $/ \# \mathrm{q}=\mathrm{El}+$ Tratado + Americano + de + Soluci $\% \mathrm{C3} \% \mathrm{~B} 3$ $\mathrm{n}+\mathrm{Pac} \% \mathrm{C} 3 \%$ AD fica + de + Controversias $+($ Pacto + de + Bogot $\% \mathrm{C} 3$ $\%$ A1) $\% 2 \mathrm{C}+$ Agenda+Internacional $\% 2 \mathrm{C}+$ (accessed 1 May 2015).

Guillaume, G., "De l'exécution des décisions de la Cour internationale de Justice» (1997), in La Cour internationale de justice à l'aube du XXIe siècle, Le regard d'un juge, Paris: Éditions A. Pedone, 2003, pp. 173-186.

Gómez-Robledo Verduzco, A., 'El 'Pacto de Bogotá' sobre solución de controversias a la luz del caso relativo a las acciones armadas fronterizas y transfronterizas entre Nicaragua y Honduras (C.I.J)", en El Papel del Derecho Internacional en América, Universidad Nacional Autónoma de México, The American Society of International Law, México, 1997, pp. 179-204.

Hudson, M., International Tribunals: Past and Future, Washington D.C.: Carnegie Endowment for International Peace and the Brookings Institution, 1944.

Infante Caffi, M.T., "El Pacto de Bogotá. Vigencia y Propuesta de Reforma", Comité Jurídico Interamericano, Cursos de Derecho Internacional, Vol. 2 (Parte 1), El Sistema Interamericano (1974-2001), pp. 1403-1063. Jiménez de Aréchaga, E., "Tentativas de Reforma del Pacto de Bogotá", Anuario Jurídico Interamericano 1986, pp. 3-11.

Jiménez de Aréchaga, E., "The Compulsory Jurisdiction of the International Court of Justice under the Pact of Bogotá and the Optional Clause", International Law at a time of perplexity, Essays in Honor of Shabtai Rosenne. Dinstein. Y. (Ed.). Dordrecht: Martinus Nijhoff Publishers, 1988, pp. 355-360.

Leoro, G., "La reforma del Tratado Americano de Soluciones Pacificas o Pacto de Bogotá", Anuario Jurídico Interamericano 1981, pp. 30-79.

Lleras, A., "El Pacto de Bogotá y la OE A. Informe sobre la IX Conferencia Internacional Americana. Antología”, Vol. V. El Diplomático, pp. 128.247, Selección de Morales Benítez, O, Bogotá: Villegas Editores, 2006. Recuperado de: http://jorgeorlandomelo.com/bajar/pactodebogota.pdf

Lupinacci, J.C., "Los Procedimientos Jurisdiccionales en el Tratado Americano de Soluciones Pacíficas (Pacto de Bogotá)", Anuario Uruguayo de Derecho Internacional, 1962, pp. 174-183

Nieto Navia, R., "La decisión de la Corte Internacional de Justicia sobre excepciones preliminares en el caso de Nicaragua c. Colombia”, ACDI -Anuario Colombiano de Derecho Internacional, Bogotá, 2009, 2, pp. 11-57. 
Recuperado de: http://www.anuariocdi.org/anuario2-capitulospdf/1_la_decision_navia.pdf

Oellers Frahm, K., "Article 94", in Simma, B., Khan, D.E., Norte, G. \& Paulus, A. (Eds). The Charter of the United Nations ( ${ }^{\text {rd }}$ ed.), Oxford: Oxford University Press, 2012.

Pillepich, A., 'Article 94', in Cot, J.P. \& Pellet, A. (Eds). La Charte des Nations Unies, Commentaire par article. Vol. II, $3^{\mathrm{e}}$ ed., Paris: Economica, 2005.

Quintana, J.J., "The Latin American Contribution to International Adjudication: the Case of the International Court of Justice", Netherlands Law Review, 1992, 39, pp. 127-154.

Quintana, J.J., "La Impugnación de la Competencia en Asuntos Contenciosos ante la Corte Internacional de Justicia", ACDI -Anuario Colombiano de Derecho Internacional, Bogotá, 2008, 1, pp. 12-48. Recuperado de: http://www.anuariocdi.org/anuario-capitulos-pdf/4_Quintana.pdf

Thirlway, H., "The Law and Procedure of the International Court of Justice". Fifty Years of Jurisprudence, Vol.II, Oxford: Oxford University Press, 2013.

Valencia-Ospina, E., "The Role of the International Court of Justice in the Pact of Bogotá", in Liber Amicorum 'In Memoriam' of Judge José María Ruda, The Hague: Kluwer, 2000, pp. 296-299.

Wellens, K." "Negotiations in the Case Law of the International Court of Justice", Farnham: Ashgate, 2014.

\section{International Court Of Justice}

- Interpretation of Peace Treaties with Bulgaria, Hungary and Romania, First Phase, Advisory Opinion, I.C.J. Reports 1950.

- Nuclear Tests (New Zealand v. France), Judgment, I.C.J. Reports 1974.

- $\quad$ Nuclear Tests (Australia v. France), Judgrnent, I.C.J. Reports 1974.

- Border and Transborder Armed Action Nicaragua v. Honduras), Jurisdiction and Admissibility, Judgement, I.C.J., Reports 1988.

- Territorial and Maritime Dispute between Nicaragua and Honduras in the Caribbean Sea (Nicaragua v. Honduras), Judgment, I.C.J. Reports 2007.

- Territorial and Maritime Dispute (Nicaragua v. Colombia), Preliminary Objections, Judgment, I.C.J. Reports 2007.

- $\quad$ Dispute regarding Navigational and Related Rights(Costa Rica v. Nicaragua), Judgment, I.C.J. Reports 2009;

- $\quad$ Aerial Herbicide Spraying (Ecuador v. Colombia), I.C.J. Reports 2008 (discontinued). 
- $\quad$ Maritime Dispute (Peru v. Chile), I.C.J. Reports 2014.

- Obligation to Negotiate Access to the Pacific Ocean (Bolivia v. Chile) (pending).

- Question of the Delimitation of the Continental Shelf between Nicaragua and Colombia beyond 200 Nautical Miles from the Nicaraguan Coast (Nicaragua v. Colombia) (pending).

- Maritime Delimitation in the Caribbean Sea and the Pacific Ocean (Costa Rica v. Nicaragua) (pending).

- Certain Activities Carried Out by Nicaragua in the Border Area (Costa Rica v. Nicaragua) (pending).

- Construction of a Road in Costa Rica along the San Juan River (Nicaragua v. Costa Rica) (Pending).

\section{Documents}

- Ministerio de Relaciones Exteriores de Colombia, Novena Conferencia Internacional Americana, Actas y Documentos, Vol. IV, 1953.

- Anteproyecto de 'Sistema Interamericano de paz e informe anexo'. Comité Jurídico Interamericano, 1945, Unión Panamericana, Washington 6, D.C., October 1945.

- Conferencia Interamericana sobre Problemas de la Guerra y de la Paz: Informe sobre los Resultados de la Conferencia presentado por el Consejo Directivo de la Unión Panamericana, México, D.F.; febrero 21-marzo 8, 1945. Unión Panamericana, Washington D.C., 1946, serie sobre Congresos y Conferencias $N^{\circ} 47$, Resolución XXXIX.

- Organización de los Estados Americanos:

- CEESI, OEA/Ser.P. CEESI/Subcom.I/doc.31/73, 23 de octubre 1973.

- CEESI, OEA/Ser.P. CEESI/Subcom.I/doc.30/73 corr.1. 24 de octubre 1973.

- Comisión Especial para Estudiar el Sistema Interamericano y Proponer Medidas para su Reestructuración. OEA/Ser.P CEESI/ doc.26/73. Vol. IV Parte 2, 8 noviembre 1973.

- Consejo Permanente de la Organización de los Estados Americanos. Comisión de Asuntos Jurídicos y Políticos, OEA/Ser.G. CP/ CAJP-663/87. 19 marzo 1987, Observaciones de los Gobiernos de los Estados Miembros al Nuevo Tratado Americano de Soluciones Pacíficas (AG/RES.821 (XVI-0/86). 
- Consejo Permanente de la Organización de los Estados Americanos. Comisión de Seguridad Hemisférica. Solución Pacífica de Controversias en la Organización de los Estados Americanos. OEA/ Ser.G CP/CSH-278/00, 13 marzo 2000. < http://www.oas.org/ csh/spanish/ncsdoc\%20soluc\%20pacif.asp\#5>(accessed 30 May 2015).

- $\quad$ CJI/RES.II-13/1985. 'Dictamen Examen del Tratado de Soluciones Pacíficas ('Pacto de Bogotá) tomando en cuenta las reservas que le han formulado los Estados signatarios del mismo, así como las razones que podrían tener algunos Estados para no ratificarlo a fin de determinar si, para asegurar su viabilidad, se requiere formular reformas a dicho instrumento'.

- Comité Jurídico Interamericano, OEA/Ser.Q/IV.3. CJI-6, Trabajos realizados por el Comité Jurídico Interamericano durante el Período Ordinario de Sesiones celebrado del 16 de agosto al 13 de septiembre de 1971, Noviembre de 1971.

- Comité Jurídico Interamericano, OEA/Ser.Q/IV.3. CJI-6, Trabajos realizados por el Comité Jurídico Interamericano durante el Período Ordinario de Sesiones celebrado del 16 de agosto al 13 de septiembre de 1971, Noviembre de 1971.

- Dictamen del Comité Jurídico Interamericano sobre el fortalecimiento del sistema interamericano de paz, Organización de los Estados Americanos, Secretaría General, Recomendaciones e Informes del Comité Jurídico Interamericano, v. X (1967/1973), Washington, 1978.

- Dictamen Examen del Tratado de Soluciones Pacíficas ('Pacto de Bogotá) tomando en cuenta las reservas que le han formulado los Estados signatarios del mismo, así como las razones que podrían tener algunos Estados para no ratificarlo a fin de determinar si, para asegurar su viabilidad, se requiere formular reformas a dicho instrumento. CJI/RES.II-13/1985.

- $\quad$ Report of the Chairman of the Informal Working Group to Study the New American Treaty of Peaceful Settlement, Permanent Council of the Organization of American States, Committee on Juridical and Political Affairs. OEA/Ser.G. CP/CAJP-686/87, 27 July 1987.

- $\quad$ Permanent Council, OEA/Ser.G CP/doc.1560/85 (Part II), 9 April 1985. 